F. C. Moore, Durham Raw Materials, P.O. Box 4142, Johannesburg; Durban, A. J. Robertson, P.O. Box 1515, Durban, Natal ; Port Elizabeth, W. Pickup, P.O. Box 3062, North End, Port Elizabeth.

\section{The Translations Bulletin}

THE Translations Bulletin of the Lending Library Unit of the Department of Scientific and Industrial Research, the first issue of which appeared in January, replaces the Translated Contents Lists of Russian Periodicals previously issued by the Unit. In so far as it also includes articles on scientific or technical developments in the U.S.S.R., the claim that it is a new publication is justified and there are also lists of translated Russian books in print or printing; translated or being translated; and suggested for publication. It represents also a considerable modification of the arrangements for co-operative Russian translations. In the new Bulletin lists are given of cover-to-cover translations of Russian periodicals and of translations of Russian articles available from the Library Lending Unit. In future, however, instead of referring to the Translated Contents Lists of Russian Periodicals previously issued by the Department at the same price as the new Bulletin, it will be necessary to subscribe to the Monthly Index of Russian Accessions, available from H.M.S.O. (U.S.A. Section), P.O. Box 569, London, S.E.1, the subscription to which is about $£ 57 s$. 6d. a year. This has the advantage of being more comprehensive than the Monthly Index, but apart from being a little later, its greater bulk may be a disadvantage in the circulation to departmental specialists on whom a university librarian, for example, will doubtless rely for requests for translations. The decision whether a translation shall be made, however, rests with the Department itself instead of with the potential user. Under the previous scheme a translation would be made at the request of two or more users, the cost depending on the number of requests received. This may, however, become less important as the co-operative scheme with the National Science Foundation for cover-to-cover translation of periodicals develops, under which twenty-four periodicals are already listed for translation in the January issue of the Bulletin.

\section{Overseas Geology and Mineral Resources}

THE quarterly bulletin of the Overseas Geological Surveys, formerly known as Colonial Geology and Mineral Resources, and published by H.M. Stationery Office, London, has been renamed Overseas Geology and Mineral Resources as from Vol. 7 (1), 1958, in order to be more in keeping with the changing status of the territories for which it caters. The bulletin will continue to cover topics concerning all the territories, whether dependent or independent, that previously came within its purview.

\section{Australian Defence Standards Laboratories}

THE 1956 report of these Laboratories has recently been released. It contains an interesting account of a surprisingly wide range of activities. The scope of the investigations is indicated by the inclusion of studies of such diverse subjects as detergents, radio spectroscopy, paint, textiles, rubber, radiological physics and viscometry. Worthy of special mention are three items of considerable interest. First, xerography has been explored with particular reference to the employment of liquid developers of high volume-resistivity such as carbon tetrachloride.
By using such liquids a considerable improvement in resolution has been achieved. This has important applications for radiographic purposes and in continuous-tone photography. Second, a new method for graticule production-the interstitial processhas been developed. This has already been described in Nature (January 24, p. 223), where the Laboratories were incorrectly named 'Reference' instead of 'Defence Standards Laboratories'. Third, work on a multi-cell-unit dry battery has produced promising results. After manufacture, the battery is dehydrated under heat and vacuum. It is then in a suitable condition for storage. When required for use, the battery is activated by the addition of water.

\section{Lady Tata Memorial Trust Scholarships and Fellow- ships}

THE Trustees of the Lady Tata Memorial Trust invite applications for grants, scholarships or fellowships for research on diseases of the blood, with special reference to leukæmia, in the academic year beginning on October 1, 1959. In view of the affinity between leukæmia and other forms of neoplastic disease, candidates with programmes of research on any aspect of malignant disease which may throw light on problems of leukæmia will also be eligible. Grants of variable amount are made for research expenses or to provide scientific or technical assistance for senior workers. Scholarships are awarded for the personal remuneration of workers carrying out approved research under suitable direction; their normal value will be $£ 600$ per annum. In addition, the Trustees may award one or more Lady Tata Memorial Research Fellowships to workers with considerable research experience; the stipends of these Fellowships will be at the rate of $£ 1,200$ per annum. Further particulars and forms of application can be obtained from the Secretary of the (European) Scientific Advisory Committee, Lady Tata Memorial Trust, Chester Beatty Research Institute, Fulham Road, London, S.W.3. Applications must be submitted before March 31 .

\section{University News :}

Bristol

Miss Margaret RANDaLl has been appointed organic chemist at the Long Ashton Research Station.

The University has received the following gifts and grants, among others: $£ 8,341$ from the British Empire Cancer Campaign for cancer research to be carried out in the Departments of Pathology, Physiology and Surgery ; $£ 2,500$ from the Department of Scientific and Industrial Research, as a renewal of grant for Prof. C. F. Powell's work in the Department of Physics ; $£ 1,492$ from the Agricultural Research Council to the Department of Veterinary Medicine for research on experimental transmission of lymphoid leukosis; $\mathfrak{£ 1 , 1 7 2}$ from the Agricultural Research Council to the Department of Physiology for research on bovine acetonæmia.

Liverpool

THE following appointments were recently made P. E. Doak, to be lecturer in applied mathematics; S. L. Dixon, to be lecturer in mechanical engineering; D. Allan, to be lecturer in applied veterinary pathology.

\section{The Night Sky in March}

NEw moon occurs on Mar. 9d. 10h. 51m. U.T. and full moon on Mar. 24d. 20h. $02 \mathrm{~m}$. The following conjunctions with the Moon take place: Mar. Id. 